Original Paper http://ajol.info/index.php/ijbcs http://indexmedicus.afro.who.int

\title{
Socio-economic analysis of processing Pachyrhizus erosus (L.) Urb. tubers into gari in Benin
}

\author{
Patrice Ygué ADEGBOLA ${ }^{1}$, Sègla Wilfrid PADONOU ${ }^{2} *$, Prosper HOUESSIONON ${ }^{3}$, \\ Nestor Ahoyo ADJOVI ${ }^{4}$, Paul HOUSSOU ${ }^{2}$, Soniade AHOUIGNAN ${ }^{3}$, Denis OLOU $^{3}$, \\ Jean Louis AHOUNOU ${ }^{2}$, Kerstin HELL ${ }^{5}$, Graham THIELE ${ }^{6}$, Pascal FANDOHAN ${ }^{2}$ and \\ Guy Apollinaire MENSAH ${ }^{1}$
}

\author{
${ }^{I}$ Centre de Recherches Agricoles d'Agonkanmey, Institut National des Recherches Agricoles du Bénin, 01 BP \\ 884 Recette Principale-Cotonou, Benin. \\ ${ }^{2}$ Programme Technologie Agricole et Alimentaire, Centre de Recherches Agricoles d'Agonkanmey, Institut \\ National des Recherches Agricoles du Bénin, 01 BP 128 Porto-Novo, Benin. \\ ${ }^{3}$ Programme Analyse de la Politique Agricole, Centre de Recherches Agricoles d'Agonkanmey, Institut \\ National des Recherches Agricoles du Bénin, 01 BP 128 Porto-Novo, Benin. \\ ${ }^{4}$ Institut National des Recherches Agricoles du Bénin, 01 BP 884 Recette principale-Cotonou, Benin. \\ ${ }^{5}$ International Institute of Tropical Agriculture, 08 BP 0932, Cotonou, Benin. \\ ${ }^{6}$ International Potato Center, Apartado 1558, Lima 12, Peru. \\ *Corresponding author; E-mail: w_padonou@yahoo.fr; Tel: +22996094839
}

\begin{abstract}
Pachyrhizus erosus is a legume plant that produces tubers rich in nutrients (protein, iron, zinc, etc.) that are used in various kinds of food processing. The objective of this study was to analyse producers' and processors' perception regarding processing $P$. erosus tubers into gari in on-farm conditions and its financial profitability. Kendall's concordance test was used to classify perceptions, and cost analysis was used to analyse the profitability of the product. The results showed that the mixed gari with $50 \%$ P. erosus was highly appreciated because of its greater fermentation ability than cassava gari. The price at which processors broke even was FCFA $340(\sim \$ 0.57)$ per kilogram and the sensitivity analysis revealed that when the yield of $P$. erosus-based gari increased by $30 \%$, processors made a profit of $25 \%$ of the investment cost. So, processing of $P$. erosus is beneficial for the processors and consumers appreciate it more than cassava gari. The Benin Government needs to promote this crop in order to feed its population.
\end{abstract}

(c) 2015 International Formulae Group. All rights reserved.

Keywords: Roots and tubers, technical performance, malnutrition, Benin, population, food quality.

\section{INTRODUCTION}

Protein-energy malnutrition and food insecurity are among the most serious problems facing tropical African countries (Bhat and Karim, 2009). It has been estimated that 800 million malnourished people live in some of the least developed countries (Myers, 2002). Underutilization of most of the crops found in this part of the world contributes to this problem. These crops include legumes, root crops and cereals - those that have been investigated have been found to be 
inexpensive and possess good nutritive value for the solution of protein-energy malnutrition (Bhat and Karim, 2009). The potential of roots and tubers for addressing the food insecurity situation in West African countries comes second only to cereals, but the utilization of these crops remains underexploited (Ayeh, 2013). Rather, tropical root crops such as cassava (Manihot esculenta Cranz, Euphorbiaceae), yams (Dioscorea L. spp., Dioscoreaceae), sweet potato (Ipomoea batatas (L.) Lam., Convolvulaceae) and cocoyams (Colocasia esculenta (L.) Schott and Xanthosoma Schott spp., Araceae) are widely grown and consumed in the tropics. All these crops are characterized by high levels of carbohydrates (starch and/or sugars) with low levels of protein. Cassava is one of the most widely consumed crops in Africa; its most popular processed product, gari, is consumed by nearly 300 million people in West Africa (Oseni, 2012). Like its raw material, a major drawback of gari as food is its low protein, and minimal essential mineral and vitamin content, a deficit in essential amino acids and resulting poor protein quality (Sanni et al., 2002; Afoakwa et al., 2010).

Benin's economy largely depends on agriculture and almost $58 \%$ of Benin's labour force works in agriculture - for a large proportion; it is their primary activity (Singbo, 2012). Roots and tubers represent one of the major crop groups grown for selfconsumption. These crops were found to be particularly important in sustainable poverty control and improvement of rural households' living conditions. Thus, roots and tubers play a very important role in achieving food security. Almost $60 \%$ of the total cultivated area in Benin is used for roots and tubers. Cassava ranks first with $34 \%$ of the cultivated area and $54 \%$ of the national roots and tubers production (Djoï and Monhouanou, 2003). Thus, the cassava sector with its multiple derivatives (gari, lafun, etc.) offers an interesting frame for the introduction of Pachyrhizus spp. in Benin (Hibon et al., 2011).
American yam bean (Pachyrhizus spp.) are storage root-forming legumes of which three cultivated species are distinguished: $P$. ahipa (Wedd.) Parodi, $P$. erosus and $P$. tuberosus (Lam.) Spreng. The plants produce heavy storage roots and large seeds, but only the roots are consumed because of the toxic compound, rotenone, contained in seeds (Kisambira et al., 2014). In the frame of the yam bean project (CIP Project $\mathrm{N}^{\circ}$ 03-13: "Enhancing the nutrient-rich Yam Bean (Pachyrhizus spp.) to improve food quality and availability and sustainability of farming systems in Central- and West AfricaAHIPA"), Pachyrhizus spp. have been introduced into Africa and are currently disseminated in five West and Central African countries, including Benin, in order to investigate its potential for food production (Heider et al., 2011).

Pachyrhizus erosus and its closely related species $P$. ahipa and $P$. tuberosus produce tubers containing greater amounts of crude proteins than cassava, reaching levels of 11-18\% (Kale, 2006; Zanklan et al., 2007) and iron up to $130 \mathrm{mg} \cdot \mathrm{kg}^{-1}$ (Kale, 2006). The physicochemical characteristics of proteins and starch from Pachyrhizus sp. have been investigated for potential agro-industrial uses (Forsyth and Shewry, 2002; Forsyth et al., 2002; López et al., 2010). Its exceptional agronomic and nutritional properties suggest that it could be adopted by consumers as well as by farming households, due to the mitigation of potential risks (Hibon et al., 2011). According to Hibon et al. (2011), P. erosus tubers can be used to produce 'gari' and 'flour'. It therefore has great potential to improve the staple food of rural populations in Benin, both quantitatively and qualitatively. It has been introduced in Benin with the purpose of processing it into gari and thereby meeting the food needs of the population. Gari from $P$. erosus contains five times more proteins than gari from cassava and, most likely, $P$. erosus gari has higher iron and zinc concentrations (Zanklan et al., 2007). According to Padonou 
et al. (2013), gari from $P$. erosus contains $4.77 \%$ proteins, $1.74 \%$ ash and $0.35 \%$ lipids.

In previous studies, Zanklan et al. (2007), Wassens (2011) and Padonou et al. (2013) demonstrated the suitability of Pachyrhizus spp. roots for gari production in West Africa. However, there is a lack of economic analysis of $P$. erosus processing and its perception among consumers. The present study aimed at analysing the profitability of $P$. erosus processing and evaluating the perception of processors and consumers of gari from $P$. erosus in an area of major gari consumption in Benin.

\section{MATERIALS AND METHODS Study zone}

The study was carried out in the following departments: Ouémé, Plateau, Atlantique, Zou and Collines, located in the southern and central part of Benin (Figure 1). It covered one or two village(s) in each department, in which roots and tubers are traditional and common crops and cassava is often processed into gari. The villages were: Wovimè in Ouémé, Mowodani in Plateau, Bossouvi in Atlantique, Togbadji and Hounvi in Zou and Gbanlin in Collines.

\section{Materials}

The material comprised tubers from two P. erosus accessions (EC-533 or CIP 209018 and EC-KEW or CIP 209019) and cassava roots. $P$. erosus tubers were provided by farmers who tried in each village the cultivation of this new crop while cassava roots were either also harvested from their farm or purchased in local market.

\section{Data}

Since women are the major actors in gari production, the experimental units consisted of women's organizations in villages where experimental $P$. erosus cultivation occurred.
The experiment was designed following the on-station trials approach reported by Padonou et al. (2013). This involved producing gari from $100 \%$ cassava (in all the sites), gari from $50 \%$ cassava + $50 \%$ P. erosus (in all the sites), and gari from $75 \%$ cassava $+25 \% P$. erosus (Affamè and Bossouvi villages only). The processing method, and the operations and equipment used were the same in all villages.

Both conventional survey method and rural participatory appraisal (PRA) were used. The conventional survey involved the use of a structured questionnaire with more emphasis on quantitative information on cost and benefits of $P$. erosus processing options. With the PRA, a semi-structured questionnairecum-checklist addressing the issues raised in the objectives was used to gather informal qualitative data and information in a more interactive manner (Quaye et al., 2009). The PRA involved individual interviews with key informants, focus group discussions with processors, and personal observations. The PRA generated supplementary information on the suitability of the various cassava processing options as well as group-based information to cross-check individual data on costs and benefits.

\section{Statistical analysis}

Quantitative data were analysed using Statistical Package for Social Scientists (SPSS) version 16.0 and MS Excel. Descriptive statistics generated from SPSS was used to present results. Data on average costs, marginal cost and benefits for the various $P$. erosus processing technologies were also generated from SPSS analysis and used in Excel for benefit-cost ratio and simulation analysis. Nonparametric test of Kendall was used in SPSS to analyse processors' and consumers' perceptions of the advantages and disadvantages of processing $P$. erosus into gari and of consumption of $P$. erosus gari. 


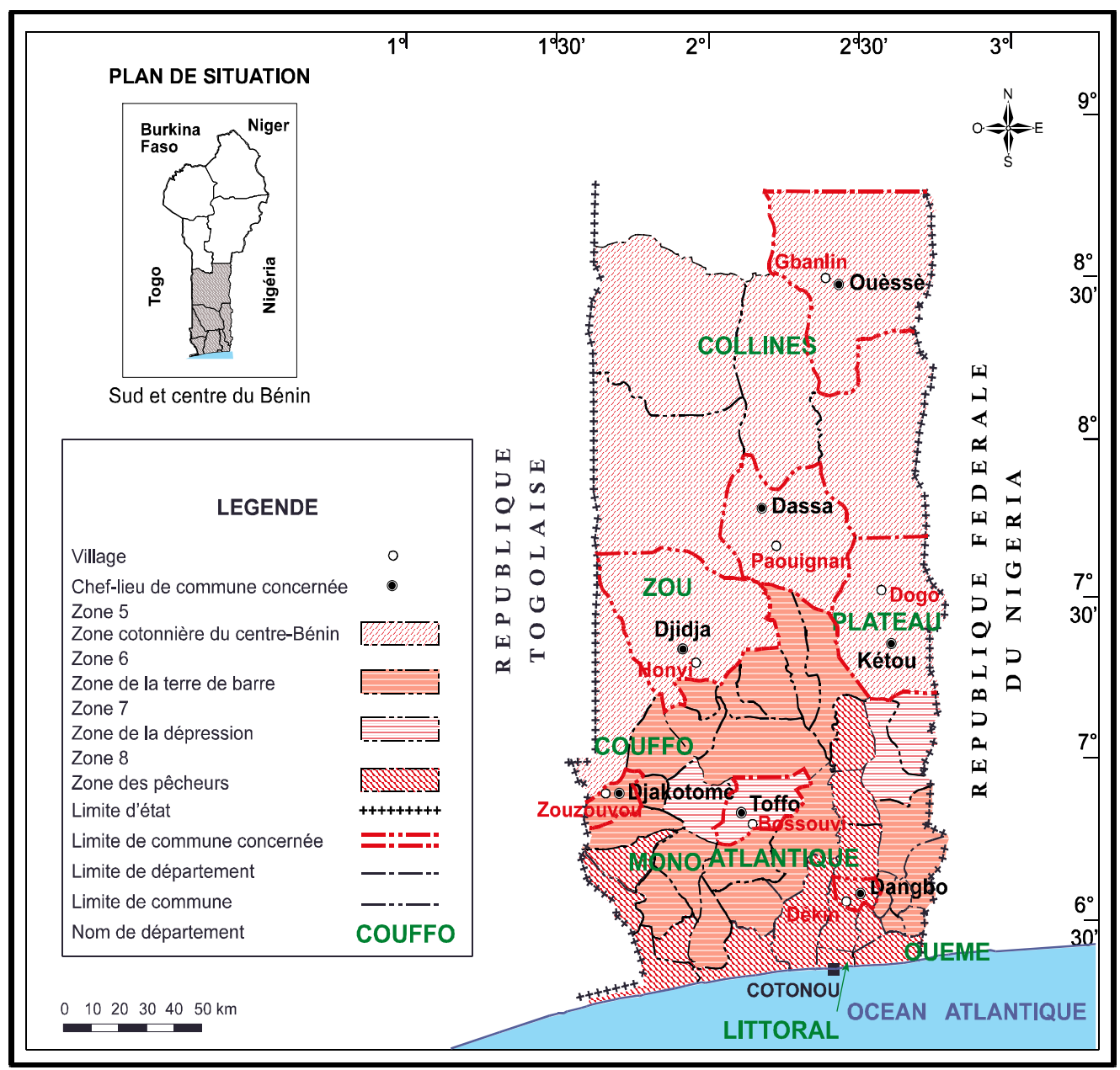

Rédigée par l'Institut Géographique National (IGN) - Août 2011 - Reproduction interdite.

Figure 1: Map of study area.

\section{RESULTS}

Analysis of constraints related to the processing of $P$. erosus into gari

Processing $P$. erosus tubers into gari in real conditions entailed the same operations required in processing cassava roots into gari. According to processors, washing and cooking were quite easy. Peeled P. erosus tubers were easy to wash because of their soft pulp that does not retain too much dirt. Likewise, $P$. erosus-based gari cooks like cassava-based gari and it can even be made crusty. Kendall's test results (Table 1) classified the difficulties met by women during the processing.
The value of Kendall's W was 0.456 significant at the threshold of $5 \%$. Thus, the major constraints were related to peeling, pressing, fermentation and breaking. Compared with cassava roots, peeling tubers was difficult and required lot of effort due to their sticky and strong skins. According to the processors from the different women organizations, pressing and grating were more difficult for $P$. erosus than for cassava. This is probably due to the fact that the grated pulp of $P$. erosus was softer and it took longer to expel water from the pulp. Fermentation duration of $P$. erosus grated pulp was relatively longer (about 1 extra hour) than cassava. Draining of $P$. erosus grated pulp, 
during which fermentation takes place, was longer than that of cassava because of the greater quantity of water in the grated pulp. Finally, breaking the pulp cake of $P$. erosus was more difficult compared to that of cassava, because the fibres of $P$. erosus seemed to be more flexible and therefore not easily breakable.

\section{Perception of the quality of $\boldsymbol{P}$. erosus-based gari}

Colour, granule size, aroma, texture during chewing and commercialization of $50 \% \quad P$. erosus gari were positively appreciated. According to the consumers, $P$. erosus-based gari was of very good quality: it was more fermentable than cassava gari, had the same granulometry, good flavour, and was very easy to chew and as easy to market as cassava gari, especially in the areas where fermented gari is favoured.

Criteria like taste, ability to make by products and weight of $P$. erosus gari were less well appreciated by the consumers compared to those of $100 \%$ cassava gari. The reasons were that $P$. erosus gari tasted slightly more sour than cassava gari.

\section{Yields during processing of $\boldsymbol{P}$. erosus gari}

Data in Table 2 show that processing yields differed from one operational unit to another. Regarding the peeling, differences observed for processing $100 \mathrm{~kg}$ of cassava, 75 $\mathrm{kg}$ of cassava $+25 \mathrm{~kg}$ of $P$. erosus, and $50 \mathrm{~kg}$ of cassava $+50 \mathrm{~kg}$ of $P$. erosus were as expected because the skin of cassava roots is thicker than that of $P$. erosus tubers. Thus, peels of $P$. erosus weigh less than those of cassava. For grating, the differences were quite small and depended on the grater. With regard to pressing, the differences observed could be explained by the fact that the grated pulp of $P$. erosus contains a lot of water compared to cassava so that, after pressing, the amount of effluent obtains was heavy compared to the small quantity of pulp. Yield gaps observed for breaking and sifting operations were related to the greater quantity of fibres contained in $P$. erosus tubers. Differences in gari yields at the end of the process were overall a result of the greater amount of water contained in P. erosus tubers. The yield of $100 \%$ cassava gari was higher than that of gari from $50 \%$ P. erosus. The ratios obtained for gari from $25 \% P$. erosus were closer to those of $100 \%$ cassava gari because of the smaller quantity of $P$. erosus tubers used in the processing. Based on these results, the economic analyses focused on mixed gari with $50 \%$ P. erosus.

\section{Duration of the unit operations during the processing of cassava and $P$. erosus into gari}

Analysis of results showed a big difference between the durations of unit operations to produce cassava gari and $P$. erosus gari (Table 3). The operations to process $P$. erosus gari took longer than operations to process cassava gari, except for grating, breaking and toasting. The longest durations were observed for peeling and pressing. Regarding peeling, this difference could be explained by the fact that tubers of $P$. erosus were more difficult to peel because of their sticky and hard skin. Also, these tubers have a round shape that does not make peeling easy. Moreover, women had not mastered the technique of peeling $P$. erosus tubers. The long duration of washing $P$. erosus is due to the fact that $P$. erosus was a new product for processors; thus, they spend more time washing it with a lot of care because of its shape. Since the tubers of $P$. erosus contain much more water, grating them was quicker.

\section{Production cost analysis}

Cost analysis (Table 4) showed that the production cost of gari obtained from $100 \mathrm{~kg}$ of raw product (50\% cassava, 50\% P. erosus) was about FCFA $7916(\sim$ \$ 13.35). The purchase price of $P$. erosus represented $44 \%$ of the production costs. Cooking represented $12 \%$ and the purchase price of cassava represented $11 \%$ of mixed-gari production costs. 
The analysis of by products (gari, peels, residue after breaking, and residue after sifting) obtained from mixing $50 \%$ P. erosus and $50 \%$ cassava revealed a revenue of about FCFA 1795 ( \$ 3.02). Gari represented 77\% of this revenue. So, among these by products, gari is the main product in terms of revenue obtained from processing. This shows that $P$. erosus tubers can be used in the production of gari.

The cost of producing mixed gari $(50 \%$ P. erosus) was FCFA 340 ( \$ 0.57) per kilogram. If a kilogram of mixed gari were to be sold at FCFA $340(\sim$ 0.57), processors would breakeven. It seems, therefore, that a sensitivity analysis needs to be conducted to identify the selling price of mixed gari of $P$. erosus that could be suitable for consumers and also provide some profit to processors. Simulations should also be done by taking in account the yield of gari in order to analyse its impact on the make-up of the processors.

\section{Economic performance}

Results of labour productivity and of the gross margin are given in Table 5. These results are calculated on the basis of the cost price in order to analyse the remuneration of household labour. Analyses showed that the gross profit was FCFA $1245.51(\sim$ \$ 2.10) for $100 \mathrm{~kg}$ of the processed mixture of $50 \% P$. erosus $+50 \%$ cassava. Labour productivity was FCFA $303.78(\sim$ \$ 0.51) per hour. Considering that a person works for eight (8) hours a day, the productivity in days was FCFA 2430.24 ( \$ 4.10). This value is higher than wage labour, which was about FCFA $1800(\sim$ \$ 3.04) in the study zones. This showed that processing $P$. erosus remunerates household labour well.

\section{Sensitivity analysis}

Analysis of technical performance revealed low yield of mixed gari of $P$. erosus. This can be mainly explained by the abundance of water in the tubers. Improving the yield by introducing varieties with higher dry-matter content could improve the revenue of women processors and thereby the cost price, the latter being linked to the quantity produced. The sensitivity analysis is based on the yield and the cost price from the scenarios used in order to identify the different possibilities of mixed gari of $P$. erosus production to satisfy processors and consumers. The different scenarios are:

- $\quad 1^{\text {st }}$ scenario: Keep the cost price constant and change the yield

- $\quad 2^{\text {nd }}$ scenario: Change the yield and the cost price.

The results given in Table 6 show the evolution of the profit in the production cost. These results showed that a yield increase up to $30 \%$ would achieve a level of profit that represents about a quarter of the production cost of gari, i.e. $25 \%$ of the cost invested in gari processing. The yield of gari corresponding to the $30 \%$ increase was 23.4 $\mathrm{kg}$. At this increase rate, the cost price of mixed gari of $P$. erosus is estimated at FCFA $261.50(\sim \$ 0.44)$ per $\mathrm{kg}$. Moreover, when the price and the yield were increased by $15 \%$, the profit reached $25 \%$ of the invested cost, i.e. a yield level of $20.7 \mathrm{~kg}$ and a kilogram selling price of FCFA 391 ( \$ 0.66).

Table 1: Classification of difficulties related to $P$. erosus processing.

\begin{tabular}{lcc}
\hline Criteria & Average rank & Rank \\
\hline Difficult peeling & 1.68 & 1 \\
Difficult pressing & 1.85 & 2 \\
Long fermentation duration & 2.47 & 3 \\
Difficult breaking & 2.90 & 4 \\
Kendall's W & $0.456^{* *}$ & \\
\hline ** Significant at the threshold of 5\%. & \multicolumn{2}{c}{}
\end{tabular}


Table 2: Average yield per unit operation during the processing of gari $(\mathrm{kg})$.

\begin{tabular}{lccc}
\hline Operations & \multicolumn{3}{c}{ Average yield } \\
\cline { 2 - 4 } & $\begin{array}{c}\text { Pure cassava } \\
\text { gari }\end{array}$ & $\begin{array}{c}\text { Gari from 25\% P. erosus } \\
\mathbf{+ 7 5 \%} \text { Cassava }\end{array}$ & $\begin{array}{c}\text { Gari from 50\% P. erosus } \\
\mathbf{+ 5 0 \%} \text { Cassava }\end{array}$ \\
\hline Fresh non-peeled & 100 & 100 & 100 \\
cassava/P. erosus & 73 & 74 & 77 \\
Peeling-Washing & 98 & 98 & 99 \\
Grating & 74 & 67 & 44 \\
Pressing & 95 & 94 & 93 \\
Breaking & 94 & 92 & 87 \\
Sifting & $\mathbf{2 3 . 1 5}$ & $\mathbf{2 0 . 9 5}$ & $\mathbf{1 4 . 3 4}$ \\
Cooked gari & & & \\
\hline
\end{tabular}

Table 3: Quantity of labor for $100 \mathrm{~kg}$ of raw materials $(\mathrm{m}-\mathrm{h})^{\dagger}$.

\begin{tabular}{lccc}
\hline Operations & \multicolumn{3}{c}{ Quantity of labor } \\
\cline { 2 - 4 } & $\begin{array}{c}\text { Pure cassava } \\
\text { gari }\end{array}$ & $\begin{array}{c}\text { Gari from 25\% P. } \\
\text { erosus }+\mathbf{7 5 \%} \text { Cassava }\end{array}$ & $\begin{array}{c}\text { Gari from 50\% P. erosus } \\
\mathbf{+ 5 0 \%} \text { Cassava }\end{array}$ \\
\hline Peeling & 2.94 & 3.55 & 5.40 \\
Washing & 0.23 & 0.38 & 0.55 \\
Grating & 0.20 & 0.18 & 0.13 \\
Bagging/Pressing & 1.21 & 2.40 & 3.22 \\
Breaking & 0.54 & 0.52 & 0.51 \\
Toasting & 5.65 & 5.29 & 4.25 \\
Sifting & 0.13 & 0.13 & 0.16 \\
Total duration & 10.90 & 12.45 & 14.22 \\
\hline$\dagger$ m-h=man-hour & & &
\end{tabular}

Table 4: Structure of the production cost of gari from $100 \mathrm{~kg}$ P. erosus and cassava (50:50).

\begin{tabular}{lccc}
\hline Items & \multicolumn{3}{c}{ Gari from 50\% P. erosus+ 50\% Cassava } \\
\cline { 2 - 4 } & \multicolumn{2}{c}{ Amount } & $\begin{array}{c}\text { Share in the total } \\
\text { production cost (\%) }\end{array}$ \\
\hline Purchase price of 50 kg of cassava & 900 & 1.52 & 11 \\
Purchase price of 50 kg of P. erosus & 3,550 & 5.98 & 44 \\
Harvesting (a) & 302.21 & 0.51 & 3 \\
Peeling (b) & 266.87 & 0.45 & 3 \\
Washing (c) & 78.75 & 0.13 & 1 \\
Water & 147.07 & 0.25 & 2 \\
Grating (d) & 317.14 & 0.53 & 4 \\
Starch extraction (e) & 229.5 & 0.38 & 3 \\
Bagging/Pressing (f) & 657.70 & 1.11 & 10 \\
Breaking (g) & 117.39 & 0.20 & 1 \\
Toasting (h) & 944.99 & 1.60 & 5 \\
firewood & 373.34 & 0.63 & 0.4 \\
Sifting (i) & 30.96 & 0.05 & \\
\hline
\end{tabular}




\begin{tabular}{|c|c|c|c|}
\hline Total production costs (1) & $7,915.92$ & 13.35 & 100 \\
\hline $\begin{array}{l}\text { Cost total labor }= \\
(\mathbf{a}+\mathbf{b}+\mathbf{c}+\mathbf{d}+\mathbf{e}+\mathbf{f}+\mathrm{g}+\mathbf{h + i})\end{array}$ & $2,945.51$ & 4.97 & - \\
\hline Income from Gari $(\mathbf{j})$ & 1,390 & 2.34 & 0.77 \\
\hline Income from peels $(\mathbf{k})$ & 69 & 0.11 & 0.04 \\
\hline Income from residue after breaking (l) & 165.79 & 0.27 & 0.09 \\
\hline Income from residue from sifting $(\mathbf{m})$ & 170.53 & 0.28 & 0.1 \\
\hline $\begin{array}{l}\text { Total costs derivative products } \\
(2)=(\mathbf{j}+\mathrm{k}+\mathrm{l}+\mathrm{m})\end{array}$ & $1,795.32$ & $\mathbf{3 . 0 3}$ & 1 \\
\hline $\begin{array}{l}\text { Production cost to be covered with gari of } \\
\text { P. erosus (3)= (1)-(2) }\end{array}$ & $6,120.6$ & 10.32 & \\
\hline Quantity of gari in $\mathrm{kg}$ & 18 & 18 & \\
\hline Cost price $(\mathrm{CP})$ & 340 & 0.57 & \\
\hline
\end{tabular}

Table 5: Labor productivity and gross margin of $100 \mathrm{~kg}$ mixture of $50 \%$ P. erosus $+50 \%$ cassava.

\begin{tabular}{lccc}
\hline \multirow{2}{*}{ Items } & \multicolumn{3}{c}{ Value } \\
\cline { 2 - 4 } & F CFA & US Dollar & man-hour \\
\hline Paid labor & 1,700 & 2.87 & - \\
Quantity household labor & - & - & 4.1 \\
Total cost raw materials & 4,450 & 7.50 & - \\
Total cost of inputs & 520.41 & 0.877 & - \\
Cost of factor except household labor & $6,670.41$ & 11.25 & - \\
Gross product & $7,915.92$ & 13.35 & - \\
Gross margin & $1,245.51$ & 2.10 & - \\
Labor productivity (per man-hour) & 303.75 & 0.51 & - \\
Capital productivity (\%) & & 1.18 & \\
\hline
\end{tabular}

Table 6: Results of simulations.

\begin{tabular}{|c|c|c|c|c|c|c|c|}
\hline Scale & $\mathbf{0 \%}$ & $5 \%$ & $10 \%$ & $15 \%$ & $20 \%$ & $25 \%$ & $30 \%$ \\
\hline \multicolumn{8}{|c|}{$\mathbf{1}^{\text {st }}$ scenario: Maintain the cost price constant and change the yield } \\
\hline Gross product (US \$) & 13,35 & 13,86 & 14,38 & 14,89 & 15,41 & 15,93 & 16,44 \\
\hline Production cost (US \$) & 13,35 & 13,35 & 13,35 & 13,35 & 13,35 & 13,35 & 13,35 \\
\hline Cost/Benefit ratio & 0 & 25,92 & 12,94 & 8,63 & 6,47 & 5,17 & 4,31 \\
\hline Corresponding cost price (US \$) & 0,57 & 0,54 & 0,52 & 0,49 & 0,47 & 0,45 & 0,44 \\
\hline \multicolumn{8}{|c|}{$\mathbf{2}^{\text {nd }}$ scenario: Change the yield and the cost price } \\
\hline Gross product (US \$) & 13,35 & 13,86 & 14,38 & 14,89 & 17,89 & 19,15 & 20,47 \\
\hline Production cost (US \$) & 13,35 & 13,35 & 13,35 & 13,35 & 13,35 & 13,35 & 13,35 \\
\hline Cost/Benefit ratio & 0 & 12,6 & 6,2 & 4,01 & 2,94 & 2,3 & 1,87 \\
\hline
\end{tabular}




\section{DISCUSSION}

Studies have been carried out to improve the nutrient content of gari through enrichment of cassava mash with protein and/or mineral-rich sources during the processing (Eke et al., 2008; Kolapo and Sanni, 2009). So, the processing of $P$. erosus tubers into the widely consumed gari would make the introduction of this new crop into West African cropping systems of interest. Adegbola et al. (2011) stated that roots of $P$. erosus can be used to produce 'gari' and 'bakery flour'. According to consumers, mixed gari with $50 \%$ P. erosus was of very good quality, i.e. more fermentable than pure cassava gari, with the same granulometry, good flavour, very easy to chew and as easy to market as cassava gari, especially in the areas where fermented gari is more popular. This confirms the results of Padonou et al. (2013) who found that mixed gari with $50 \%$ P. erosus had better quality than pure cassava gari. From their evaluation of the quality of $P$. erosus gari and $P$. erosus fortified gari, Padonou et al. (2013) concluded that the protein content increased by more than $30 \%$ when $50 \%$ P. erosus was included in the processing with cassava, and the gari was whiter in colour and panellists scored it well. The yield of $100 \%$ cassava gari was higher than that of the $50 \%$ P. erosus-based gari, due to the greater amount of water contained in $P$. erosus tubers. According to Grüneberg et al. (2003), Balbin et al. (2005), and Zanklan et al. (2007), with a view to improving the yield of garification, there is a need to evaluate the potential of making gari from yam bean Chuin type ( $P$. tuberosus), which has high dry-matter content, combined with high protein content. The lower yield of mixed gari of $P$. erosus could also explain its cost price estimated at FCFA $340(\sim \$ 0.57)$ per $\mathrm{kg}$. This price is greater than cassava gari's price which was about FCFA $150(\sim 0.25)$ per kg. By taking into account the nutrient characteristics of mixed gari, consumers would be better off health-wise consuming mixed gari with 50\% $P$. erosus. The major problem was the decrease of the yield of gari obtained by mixing $50 \% \quad P$. erosus with cassava. Improving the yield by introducing varieties with high dry-matter content could improve the revenue of women processors and thereby the cost price, the latter being linked to the quantity produced.

\section{Conclusion}

The present study and the results obtained allowed identifying difficulties related to the processing of mixed gari made with $50 \%$ P. erosus. Technical and financial results and the appreciation of processors showed that mixed gari of 50\% P. erosus is edible and can be commercialized. However, the high water content of $P$. erosus makes the gari yielded quite low, preventing those processing these tubers into gari from making more profit. Sensitivity analyses showed that increase in yield of mixed gari of 50\% $P$. erosus improves processors' profit, giving producers the opportunity to reduce unit sale price and thereby improve marketability. Research on gari processing should therefore be directed to other varieties with tubers containing less water.

\section{ACKNOWLEDGEMENTS}

This research was funded by the Belgium Government through the International Potato Center (CIP) in the frame of the project "Enhancing the nutrient rich yam bean (Pachyrrhizus spp.) to improve food quality and availability and sustainability of farming systems in Central and West Africa." The authors wish to thank CIP and the authorities of the National Agricultural Research Institute of Benin for technical support.

\section{REFERENCES}

Adegbola YP, Djenontin INS, Sossou CH, Hinnou CL, Thiele G, Mensah GA. 2011. Etude Diagnostique Participative pour le Projet Ahipa au Bénin. CIP/INRAB ; p. 170. 
Afoakwa EO, Kongor EJ, Annor GA, Adjonu R. 2010. Acidification and starch behaviour during co-fermentation of cassava (Manihot esculenta Crantz) and soybean (Glycine max Merr) into gari, an African fermented food. Int. J. Food Sci. Nutr., 61: 449-462.

Ayeh SE. 2013. Development and quality characteristics of yam bean (Pachyrhizus erosus) flour and its performance in bread. MSc thesis, Kwame Nkrumah University of Science and Technology, Kumasi, Ghana, p. 114.

Balbin IO, Delgado-Vásquez O, Carhuanca KM, Sørensen M, Kvist LP. 2005. El Cultivo de Chuin (Pachyrhizus tuberosus): una Alternative Para la Seguiridad Alimentaria y Recupereción de Suelos Degradados en la Amazonía Peruana. Lima: Peru; 40.

Bhat R, Karim AA. 2009. Exploring the nutritional potential of wild and underutilized legumes. Compr. Rev. Food Sci. F., 8(4): 305-331.

Djoï D, Monhouanou JD. 2003. Etude de Marché National sur les Racines et Tubercules et Produits Dérives. MAEP/PDRT : Bénin.

Eke UB, Owalude SO, Usman LA. 2008. Enrichment of a cassava meal (Gari) with soyabean protein extract. Adv. Nat. Appl. Sci., 2: 60-62.

Forsyth JL, Shewry PR. 2002. Characterization of the Major Proteins of Tubers of Yam Bean (Pachyrhizus ahipa). J. Agric. Food Chem., 50: 19391944.

Forsyth JL, Ring SG, Noel TR, Parker R, Cairns P, Findlay K, Shewry PR. 2002. Characterization of Starch from Tubers of Yam Bean (Pachyrhizus ahipa). J. Agric. Food Chem., 50: 361-367.

Gruneberg WJ, Freynhagen-Leopold P, Delgado-Vaquez O. 2003. A new yam bean (Pachyrhizus spp.) interspecific hybrid. Genet. Resour. Crop Evol., 50: 757-766.
Heider B, Tumwegamire S, Tukamuhabwa P, Ndirigwe J, Bouwe G, Bararyenya A, Hell K, Leclercq J, Lautié E, Wassens R, Burgos G, Zumfelde T, Thiele G, Grüneberg W. 2011. Nutritional improvement of yam bean and sustainability of farming systems in Central and West Africa. Afr. Crop Sci. Conf. Proc., 10: 93-95.

Hibon A, Adegbola PY, Hell K, Thiele G. 2011. Contraintes et Opportunités pour l'Introduction de Nouveaux Produits sur les Marchés Locaux des Racines et Tubercules au Bénin. International Potato Center (CIP): Lima, Peru.

Kale PR. 2006. Studies on nutritional and processing properties of storage roots of different yam bean (Pachyrhizus spp.) and wild mung bean (Vigna vexillata) species. PhD. thesis, Universitat Gottingen, Cuvillier Verlag, Gottingen, Germany.

Kisambira A, Muyonga JH, Byaruhanga YB, Tukamuhabwa P, Tumwegamire S, Gruenberg W. 2014. Physicochemical Characteristics of Yam Bean (Pachyrhizus erosus) Seed Proteins. J. Food Res., 3(6): 887-895.

Kolapo AL, Sanni MO. 2009. A comparative evaluation of the macronutrient and micronutrient profiles of soybean fortified gari and gari. Food Nutr. Bull., 30: 9094.

López OV, Viňa SZ, Pachas ANA, Sisterna MN, Rohatsch PH, Mugridge A, Fassola HE, García MA. 2010. Composition and food properties of Pachyrhizus ahipa roots and starch. Int. J. Food Sci. Technol., 45: 223-233.

Myers W. 2002. In Sustainable food security for all by 2020. Proceedings of the International Conference on Food Security, Bonn (Germany), September 46, 2001, Washington DC, IFPRI, p. 100.

Oseni AL. 2012. Empowerment initiatives: Garri processing empowers women. West Africa Insight, 3(6): 3-5. 
Padonou SW, Houyèvou Klotoe A, Ahounou J-L, Houssou PA, Fandohan P, Aïhou K, Adjanohoun A, Hell K, Adégbola PY, Mensah GA, Koudandé OD. 2013. Yam bean (Pachyrhizus erosus) tuber processing in Benin: Production and evaluation of the quality of yam bean-gari and yam bean-fortified gari. Int. J. Biol. Chem. Sci., 7: 247-259.

Quaye W, Yawson I, Gayin J, Plahar WA. 2009. Economic Comparison of Cassava Processing Methods in Some Selected Districts of Ghana. Afr. J. Root Tuber Crops, 35(2): 211-218.

Sanni AI, Marlon-Guyot J, Guyot JP. 2002. New efficient amylase-producing strains of Lactobacillus plantarum and
Lactobacillus fermentum isolated from different Nigerian traditional fermented foods. Int. J. Food Microbiol., 72: 53-62.

Singbo A. 2012. Analyzing efficiency of vegetable production in Benin. $\mathrm{PhD}$ thesis, Wageningen University, the Netherlands, p. 128.

Wassens R. 2011. Assessment of the suitability of yam bean for the production of gari. MSc thesis, Wageningen University, the Netherlands, p. 82.

Zanklan AS, Ahouangonou S, Becker HC, Pawelzik E, Grüneberg W. 2007. Evaluation of the storage root-forming legume yam bean (Pachyrhizus spp.) under West African conditions. Crop Sci., 47: 1-14. 